\title{
TOWARDS THE FORMULATION OF A PEDAGOGICAL FRAMEWORK FOR ISLAMIC SCHOOLS IN AUSTRALIA
}

\author{
Muhammad Abdullah*, Mohamad Abdalla**, Robyn Jorgensen***
}

\begin{abstract}
During the last 30 years 'Islamic' or Muslim schools have sprung up in Europe, North America and Australia. Reasons for the establishment of these schools generally pertain to Islamic faith and quality of education. Parents desire their children to be positive participants in, and contributors to, society while at the same time maintaining their faith. However, a number of researchers question the effectiveness of Islamic schools in achieving these goals. Driessen and Merry (2006) and Walford (2002) note that matters of Islamic faith are mainly confined to formalities expressed as rules and codes and Qur'an recitation. Moes (2006) and Shamma (1999) express concern that formalisation of religious education leads to negative consequences. Often, these schools devote their energies to the 'what' and 'why' of Islam without the 'how'. Memon (2007) proposes that to achieve the intents and purposes of Islamic education in a western context, teachers need to be guided by the pedagogical principles of the Islamic tradition in a fertile synthesis with the pedagogical principles of contemporary educational thought. Such a pedagogical framework would enable a curriculum to be embedded that is both faithful to Islamic principles and relevant to contemporary society. While there is some limited international research in this area, there is a dearth of research in the Australian context. This paper critically surveys and evaluates the existing research material and proposes a Prophetic Pedagogical Framework that may be used in a fertile synthesis with the Productive Pedagogies framework underpinning the Queensland public education system. It is contended that an Islamic extension of the Productive Pedagogies framework would have considerable value for the on-going quality of teaching in Australian Islamic schools.
\end{abstract}

\section{Introduction}

Muslims are no strangers to Australia; Northern Australia is marked on the maps of the Arab geographers of the $9^{\text {th }}$ and $10^{\text {th }}$ centuries of the Common Era (Cleland 2001). From the $17^{\text {th }}$ century to 1907 the Macassans, from southern Sulawesi in Indonesia, were regular traders with the Aboriginal Yolngu people of Arnhem Land while in the east during the early days of the colony Muslims arrived both as free settlers and convicts. However, there are no records of the existence of mosques until after the arrival of the 'Afghan' cameleers in 1860. The oldest mosque still fully utilised was founded in Adelaide in 1895. 
Different Muslim ethnic groups have migrated since that time but it was not until the late 1960s and 70s that significant numbers of Muslims migrated to Australia (Cleland 2001).

Since the 1970s Muslims have migrated from over seventy countries (Wise and Ali 2008:14) and although the representation in the popular media is of a uniform and homogenous group they come from a range of theological traditions and encompass different cultural, sectarian, linguistic, and ethnic values (Wise and Ali 2008:11). A large number of these migrants come from countries which are in themselves culturally and religiously diverse. Like other migrants they come for a multitude of reasons including economic advantages, educational opportunities, family reunion and escape from political oppression (Wise and Ali 2008:14). Muslims have followed the tendency of other migrant groups in settling close to each other. However given the importance of family and the mosque in Islam, subsequent generations have continued this tendency (Wise and Ali 2008:14-15). With the advent of larger communities from the 1960s and 70s the construction of more mosques became both an imperative and a possibility. These mosques were not only used for prayer gatherings but as centres for children's' religious education particularly Qur'an recitation. As the numbers of Muslim students grew, sentiment developed within the community that a quality religious experience could more readily be achieved by the establishment of full time Islamic schools. By 1983 the first of these schools had been established in Sydney, Melbourne and Perth. In the following thirty-two years more than thirty Islamic primary, secondary and k-12 schools have been established across Australia.

During the same period a similar growth in Islamic schools has been experienced in other migrant communities across North America and Europe. Given that it is the 'Islamic' that is the rationale for the differentiation of these schools from public and other faith based schools it is pertinent to examine the nature of this differentiation.

\section{Islamic Schools: The International Experience}

Driessen and Merry (2006) reviewed studies of Netherland's Islamic schools undertaken between 1989 and 2002. The empirical studies Driessen and Merry reviewed included those performed by the Dutch Inspectorate of Education (DIE), the National Security Centre (NSS) and two undertaken by university researchers, Shadid and Van Koningsveld (1992), and Driessen and Bezemer (1999). Driessen and Merry (2006) found, that after taking into consideration the different perspectives and intent of each of these studies, students in Dutch Islamic schools do no more poorly than students at schools with a comparable 
socio-ethnic background. However matters of Islamic faith are generally confined to lessons in Qur'an recitation and formalities expressed as rules and codes imposed by the board on staff and students.

Islamic schools in Britain seem to perform better academically than their Dutch counterparts. In a comparison of all schools, both religious and nonreligious, Islamic schools were among the most successful in terms of valueadded scores and raw exam results in 2007 (TES website). The three Islamic primary schools measured were joint top in key English tests but lowest in contextual value-added (CVA) scores, which factor in student background and prior attainment, suggesting that students should have achieved better results (Marley 2008).

As a majority of British Islamic schools suffer from a shortage of funds, they consequently lack many of the facilities available in state schools (Meer 2007:61). It is therefore understandable that Muslim schools in Britain would seek to become voluntary aided schools and feel the need to highlight academic achievements. This continues to leave Islamic faith, as Walford (2002) found, confined in the main to formalities and the introduction of Islamic and Qur'anic studies as subjects merely appended to a standard public education curriculum.

Despite the dramatic increase of Islamic schools in North America over the last few years, ongoing financial pressures prevent many schools from fulfilling the claims of excellence initially promised (Merry and Driessen 2005:424). However, academic excellence is high on the agenda and the overwhelming majority of Islamic schools eagerly seek outside assistance from other nonIslamic schools and enthusiastically embrace accountability both at local and state levels (Merry and Driessen 2005:427).

This prioritisation of academic excellence results in Islamic faith requirements being addressed merely by the addition of decontextualized courses in Arabic, Qur'an memorisation and Islamic studies. This creates a situation where at best the classes produce factually knowledgeable students uncommitted to Islam and at worst students who turn away from Islam (Moes 2006:11)

\section{The Australian Experience}

In 2006, 20\% of Muslim students attended independent schools, a significant rise from the 9\% in 1996 (Buckingham 2010). The vast majority of these students attended Islamic schools. Clyne (2000) conducted parental interviews to identify the reasons why Muslim parents send their children to Islamic schools. She found the more important reasons were that the Islamic school curriculum reflects Islamic values; there is strong discipline; a Muslim environment; the 
teachers understand about Islam; Qur'anic studies are taught; and that children will learn correct behaviour (Clyne 2000:199-200).

While there are currently no comprehensive studies in Australia that evaluate the extent to which Islamic schools' fulfil parental expectations; the observations of Sanjakdar (2005) at two Melbourne schools are informative. She found that despite the claims of delivering a holistic Islamic education it was difficult to find evidence of Islamic teaching principles and beliefs as the theoretical model for curriculum planning and practice (Sanjakdar 2005:2). Staff were concerned that the drive for academic success had made the college forget its religious obligations and commitment to parents. Islam had become restricted to a few periods of Qur'anic and Islamic studies per week. This restricted class time and the fragmented approach of Islamic education in the core curriculum made it difficult for students to view Islam as a long life activity, extending beyond the limits of formal schooling (Sanjakdar 2001).

The work of Sanjakdar (2001 \& 2005) cannot be extrapolated to reflect all Islamic schools in Australia; however given the concordance with the experiences of Islamic schools in other western contexts it is reasonable to expect that it does at least reflect the situation of a significant number of other Islamic schools in Australia.

Watson and Chen (2008) undertook a study at an Islamic School in Sydney as part of, 'The Teacher Education for the Future Project'. The Project seeks to inform teacher education programs about the educational challenges and changes in society for the $21^{\text {st }}$ century, to better inform the education of global citizens of the future. The project employs a survey to probe teachers' beliefs about the purpose of education and how best to prepare teachers for the future. Of the 41 teachers at the school, 26 responded to the survey, 19 female and 7 male. Of these respondents $73.7 \%$ of the females and $28.6 \%$ of the males identified as Australian. In response to questions about the purpose of education no teacher responded that preservation of culture is important. On inquiry as to why this option was not selected the women responded:

Since the Cronulla riots we (Muslims) do not want to be seen as different ... We want to just melt into the background and disappear. We know this will not happen because we (a group of women) dress differently ... But we still don't want to write that we want this difference. We feel ashamed. We shouldn't feel like this ...We just want to be Australians like everyone else. We love our religion and we want to be Australians $\ldots$

It is worthy of note that the women, while affirming their attachment to Islam and an Australian identity, do not see themselves as preservers of culture. 
This awareness of a 'new world' to that of the parents is further elucidated in a female geography teacher's response concerning teacher education, "teacher education should produce teachers who are able to produce citizens who are independent, realistic thinkers and productively contribute to their welfare and that of society" (Watson and Chen 2008: 44).

\section{Cultural Traditions and Islam}

In their article discussing culturally appropriate cognitive therapy with Muslim clients, Hodge and Nadir (2008:33) note that in contrast to the individualism, rooted in European enlightenment, that is valued by Western counselling, Islam highlights the importance of community and as a consequence rather than looking inward to establish identity, Muslims tend to look outward, grounding their identity in religious teachings, culture and family. This importance of culture is noted by Wise and Ali (2008:11) who point out that Muslims in Australia practice their religion in accordance with the cultural traditions of their individual countries, and in some cases according to different ethnic traditions within these national cultural traditions. The Islamic cultural traditions of these countries have developed over time as Murad (1997:6) notes:

The traditional Muslim world is a rainbow, an extraordinary patchwork of different cultures, all united by a common adherence to the doctrinal and moral patterns set down in Revelation. Put differently, Revelation supplies parameters $(h u d u d)$ rather than a complete blueprint for the details of cultural life.

The interaction between Islam and local traditions from the beginning of Islam has always been dynamic and therefore it is natural that with time Australian born Muslims will develop their own distinct Australian Islamic cultural traditions. A process Watson and Chen (2008) reveal is already underway. This highlights the significance of Moes's comment, that if students feel religion is being used insincerely as a tool to ensure cultural conformity with an 'old world' standard, they will be more likely to rebel (Moes 2006:10). Children born in Australia are part of Australian society and therefore attempts by parents to protect children from the influences of society by placing them in Islamic schools can easily be interpreted by their children as a culture gap rather than a religious need. In some cases, expectations of conformity from parents have led to an outward compliance but inward rebellion against Islam (Moes 2006:9).

Given the issues raised above it is understandable why some critics of Islamic schools have concerns in regards to the ability of Islamic schools to 
prepare children to live in a multicultural society, and to reflect critically upon their inherited beliefs and cultural norms (Merry and Driessen 2005:428).

\section{A Possible Way Forward}

The Qur'an and hadith are the original sources for the three different terms generally used to denote the concept of education in various Islamic Arab countries today. Each of these terms emphasise different aspects of the development of the whole person represented by the physical, intellectual, moral and spiritual dimensions (Boyle 2004:15). The first term ta'lim refers to instruction and learning about things, which develops reason and trains the mind, as stated in the Qur'an 'And He [God] taught ('allama) Adam the names of all things' (2:31), and the saying of the Prophet 'the best of you are those who learnt (ta'allama) the Qur'an and taught it ('allama) (An-Nawawi hadith 1000: 303). The second term tarbiyah refers to the development of human personality and the nurturing and rearing of a child (Qur'an 17:24), and the third term $t a$ 'dib refers to the training of the mind and soul in terms of behaviour and ethical conduct. It encompasses the recognition and acknowledgement of one's right and proper place and the self-discipline to enact one's role in accordance with that place (Attas 1980:22).

The term, tarbiyah, is used by Tauhidi (2001) to name his vision for Islamic education in North America: the Tarbiyah Project. This he envisages as a holistic and integrated approach that aims to nurture the character and inner spirit of the child to enable self-discovery, wholeness and social consciousness. To achieve this, he proposes that Islamic spirituality be woven throughout the curriculum and into the daily learning experience of the student. However, Attas (1980:28-33) points out that the use of the term tarbiyah to denote education is a modern construct, and does not lend itself to a concept of Islamic education and its essential elements of knowledge, intelligence and virtue. For earlier generations, the term tarbiyah was not intended to denote education or the education process, but signified the cherishing that parents bestow on their children. Attas (1980:24-27) argues that education is in fact $t a$ 'dib because the earlier Muslims combined 'ilm (knowledge) with 'amal (concomitant action). Adab is what joins the 'ilm to 'amal by the recognition and acknowledgement of the right and proper place for the willing enactment of one's role.

However, the opinion of Bin Omar is that an accurate definition encompasses all three aspects and is concerned with developing the essence of the human being (the soul-spirit, heart, self, and intellect) (Boyle 2004:15). Memon and Ahmed (2006:16-18) encompass these aspects in the term Adamic Education, coined by Abdul Hakim Murad (2001) (aka T. J. Winter). 
This view is based on the movement of Adam from heaven to earth, a movement they argue is a spiritual ascent rather than a fall because he moved from a state of ignorance to a state of knowledge, and therefore through education Adam was raised to be the vice-gerent of God on earth. The vicegerent has correct $a d a b$ in that their behaviour is appropriate and fitting for the occasion and has been performed in due proportion in a conscious state of being, as if seeing God. Education is thus not a forward movement to things unknown but a search for knowledge to return to a state of fitrah (natural state of purity). Therefore education is not just transmission of knowledge but human transformation.

Memon (2007:3) sees immense value in the definitions discussed above but argues that limiting a definition to one or the other of the aspects does not give justice to the expansiveness of the Islamic teaching tradition. Although he does not explicitly follow Bin Omar in his synthesis of all three aspects to define Islamic education, they are all embedded in his discussion.

Memon (2007) argues that for Islamic schools to raise standards in Muslim students' preparation for the challenges of life in Western and contemporary society, curriculum and assessment need to be embedded in an authentic Islamic pedagogy. Muslims in Western and contemporary society face life experiences that are ostensibly different from previous generations. Memon (2007:2) points out historically Islamic schools in the west have erroneously assumed that Muslim teachers - by virtue of being Muslim - know what it means to educate Islamically, and as a result Islamic schools have focused any spare energy on the area of curriculum development. He therefore argues for a shift in effort from revisiting curriculum initiatives to teacher training initiatives. This, he argues, will enable improvements in standards.

Memon also argues that the 'Islamic' character/nature of an Islamic school should not be dependent on curriculum only, but must essentially be linked to an appropriate pedagogy. Hence, for the purposes of Islamic schools in Western contexts it is proposed that a "fertile synthesis" between the pedagogical principles of the Islamic tradition and that of contemporary educational thought be formulated in order to achieve the intended aims of Islamic schooling (Murad as cited in Memon 2007:12).

\section{Productive Pedagogies}

For Islamic schools in Australia, it is contended that a synthesis between Productive Pedagogies and Prophetic pedagogy would allow the achievement of the intended aims and objectives of Islamic schooling. The Queensland School Reform Longitudinal Study (QSRLS) is one of largest classroom based 
research projects ever undertaken in Australia. The study was commissioned by Education Queensland (EQ), and commenced in 1997 with the submission of the final report in 2001. The QSRLS observational data led to the four dimensions of the Productive Pedagogies framework, which has been taken up widely in Australia and internationally as both a research tool and a metalanguage for critical teacher reflection (Mills et al 2009). Productive Pedagogies was adopted by Education Queensland in 2001. Another similar framework based on the QSRLS data is The Quality Teaching Model, which was adopted by the NSW Department of Education and Training in 2006.

The twenty elements of the framework are grouped in four dimensions: Intellectual Quality, Connectedness, Supportive Classroom Environment and Recognition of Difference.

The Productive Pedagogies framework has been chosen in preference to the Quality Teaching Model for use in a 'fertile synthesis' with prophetic pedagogy for the following reasons.

- Its wide use within Australia and internationally as a research tool and metalanguage.

- Group identity and citizenship are not included in the Quality Teaching Model but are potentially significant in the construction of pedagogy for Islamic Schools

- The twenty elements of the Productive Pedagogies Framework are basically the twenty classroom practices that formed a lens for the structured observations undertaken in the QSRLS research.

- The QSRLS (1997-2001) is currently being revisited in a recently commenced six-year study, the Queensland Longitudinal Study of Teaching and Learning.

\section{Methodology for identifying Pedagogical Principles of the Islamic tradition}

Islam is a complete way of life. It's moral, spiritual, legal, financial, educational and ethical guidance is derived through Islam's primary revealed sources: the Quran and Sunnah. The Quran deals with specific and general themes such as monotheism (tawhid), morals and ethics, the hereafter, the stories of past nations, and the cosmos. The Sunnah is defined as the sayings, actions and tacit approvals of Prophet Muhammad, and it expands on the themes of the Quran and is a practical manifestation of the ideal Islamic life.

As Du Pasquier (1992) points out; "in Islam everything belongs to God and every aspect of human and social life is sanctified through the tradition proceeding from the revelation; the Prophet is the exemplification of that 
tradition, "His example gives the believers the possibility to fully realise their human condition while maintaining spiritual orientation" (Du Pasquier 1992: 48). This is expressed in the following verses of the Qur'an; "For you in the messenger of Allah [God] is an excellent example" (Qur'an 33:21), and "For this we have sent a messenger to you from amongst you reciting to you Our signs, purifying you, teaching you the Book and wisdom and teaching you what you previously did not know" (Qur'an 2:151).

The Sunnah has been preserved throughout the annals of Islam in collections known as the Hadith. A scientific approach was developed by classical Islamic scholars to filter out the authentic hadith from other less reliable narrations. The Hadith have been classified and collected in numerous compilations, however two of these, Sahih Bukhari and Sahih Muslim are the most well-known compilations in which all the hadith are accepted by the majority of traditional Islamic scholars as rigorously authenticated.

To identify the main elements of the pedagogical principles of the Islamic tradition as exemplified by the teaching of the Prophet it is necessary to examine the Hadith. For the purposes of this research the compilation of Sahih Muslim was preferred due to its more integrated structure and accessibility for non-specialist hadith scholars (Ali 2003:104). To minimise the potential of bias in hadith selection and a resultant skewing of results it was decided to use a Glaserian grounded theory approach of systematic coding and analysis by constant comparison of hadith from Sahih Muslim starting from the beginning of the compilation. Glaser's approach was selected given its more purely inductive nature and flexibility (Urquhart 2001). The method involves theoretical sampling and analysing by constant comparison. This continues until the point of saturation - the point in sampling when the categories, their properties and dimensions, as well as the links between the categories, are well established and the beginning of an emergent theory and a core variable is evident (Holloway 2008: 112-114).

However, it should be noted that in coding the hadith identification of a single core variable from the outset was not intended, but rather a number of core variables that would equate with pedagogical principals from the life of the Prophet Muhammad. These core variables were labelled in the analysis as core categories in order to avoid confusion with the core variable of emergent theory. When the analysis was tabulated the core categories were renamed Elements. Table 1 gives examples of coded hadith that were included in categories that were later linked together in the Element (core category) Differentiation. 
Table 1. An example of an Element (core category) and some included codes

\begin{tabular}{|c|c|}
\hline ELEMENT & EXAMPLES OF HADITH USED IN CODING \\
\hline Differentiation & \\
\hline $\begin{array}{l}\text { Addresses according to the } \\
\text { ability of the listener }\end{array}$ & $\begin{array}{l}\text { Hadith 6: It is reported from Abu Hurairah that a Bedouin } \\
\text { came to the messenger of Allah (may Allah grant him } \\
\text { blessings and peace) and said: O Messenger of Allah guide } \\
\text { me to a deed that if I do it I will enter paradise. He said, } \\
\text { Worship Allah and do not associate anything with Him, } \\
\text { establish the obligatory prayer, pay the Zakat (tax on the } \\
\text { rich paid to the poor, needy, orphans etc.) and observe the } \\
\text { fast of Ramadan. He said: By Him in Whose hand is my } \\
\text { life, I will never add anything to it nor will I do less than it. } \\
\text { When he turned to leave, the Prophet (may Allah grant him } \\
\text { blessings and peace) said: Whoever is pleased to see a man } \\
\text { from the dwellers of paradise should look at him. }\end{array}$ \\
\hline Non-verbal strategies & $\begin{array}{l}\text { Hadith 46: It is narrated that Abu Masud said; The Prophet } \\
\text { of Allah (may Allah grant him blessings and peace) pointed } \\
\text { in the direction of Yemen and said, Indeed Iman (faith) is } \\
\text { here.... }\end{array}$ \\
\hline \multirow[t]{2}{*}{$\begin{array}{l}\text { Teaches using himself and } \\
\text { others as examples }\end{array}$} & $\begin{array}{l}\text { Hadith 99: it is narrated from Abu Hurairah that the } \\
\text { Messenger of Allah (may Allah grant him blessings and } \\
\text { peace) passed by a pile of food; he put his hand into the pile } \\
\text { and his fingers became wet. He said; O food vendor, what } \\
\text { is this! He said; It has been affected by rain O Messenger of } \\
\text { Allah. He said; Wouldn't it have been better to put it on top } \\
\text { of the food so that the people could see it? Whoever cheats } \\
\text { is not from us. }\end{array}$ \\
\hline & $\begin{array}{l}\text { Hadith 2: It is narrated from Abu Hurairah that the } \\
\text { Messenger of Allah (may Allah grant him blessings and } \\
\text { peace) in public with the people. A man came to him ... } \\
\text { He said; O Messenger of Allah, when is the Hour? He said, } \\
\text { the one who is asked is no more knowledgeable than the } \\
\text { questioner but I will inform you about its signs. (models } \\
\text { politeness and completeness of reply) }\end{array}$ \\
\hline
\end{tabular}


Core categories that were identified after the initial one hundred and seventy-one hadith were systematically coded and analysed through constant comparison. These core categories made up the elements of the draft Prophetic Pedagogical Framework. The specific understanding and meanings of the core category and category names are teased out in the features of the various Elements of the draft Prophetic Pedagogical Framework at Table 2. The descriptions in italics represent categories included in the core categories (elements).

The element 'Memorisation as a key' has been included in addition to the core categories because of the central nature of oral transmission to Islamic religious education from the very inception of Islam up until the present day (Hardaker and Sabki 2010 \& Boyle 2004). 


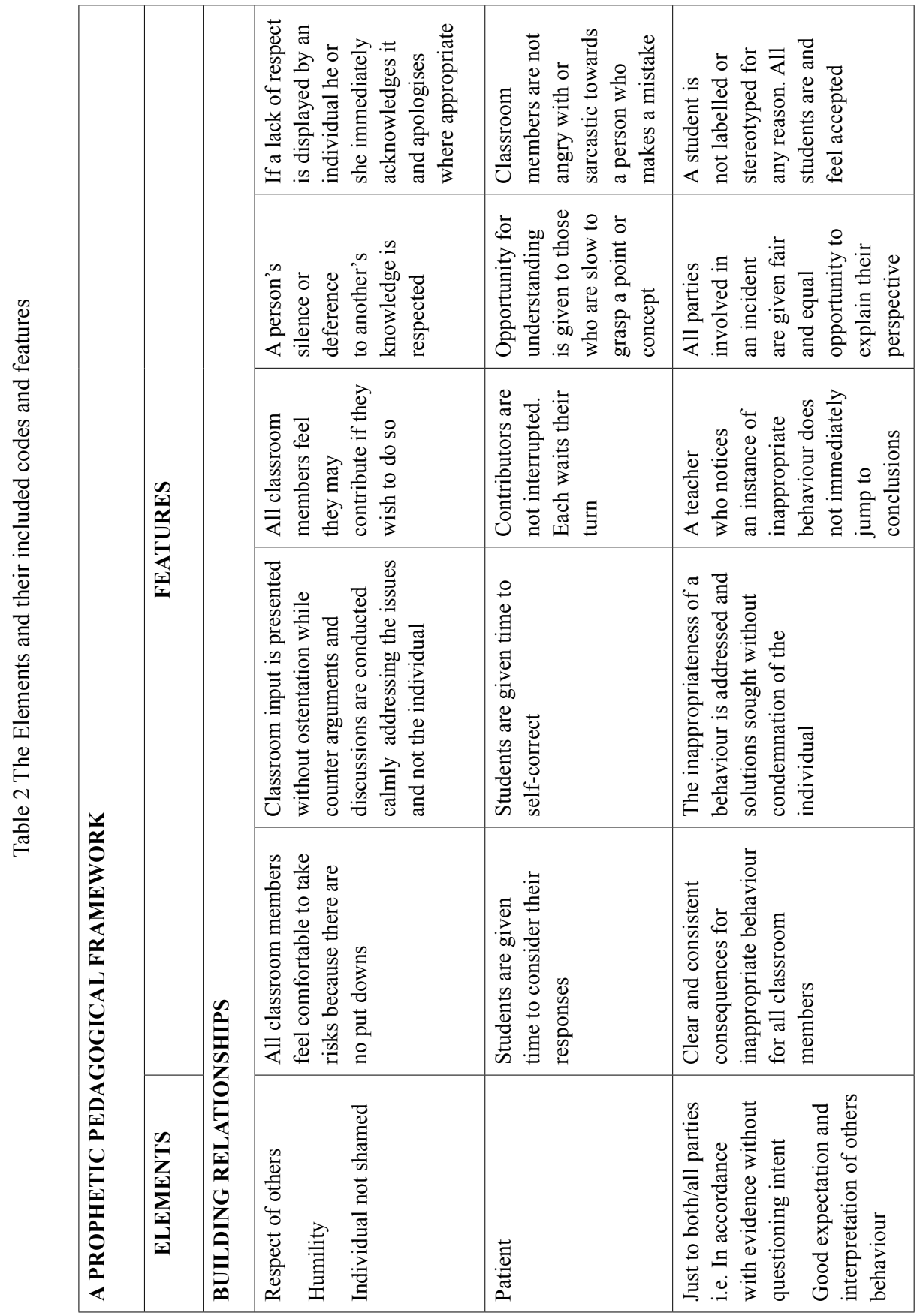




\begin{tabular}{|c|c|c|}
\hline 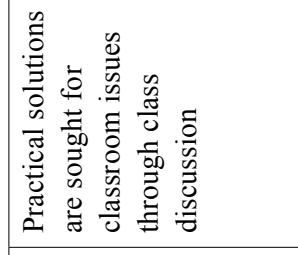 & & 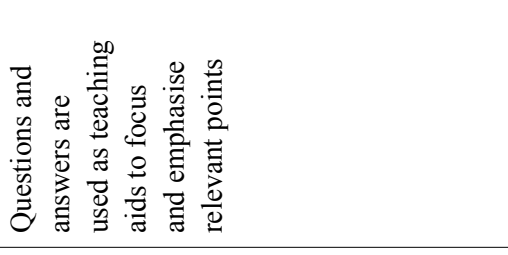 \\
\hline 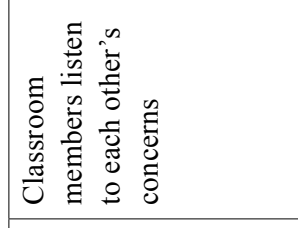 & & 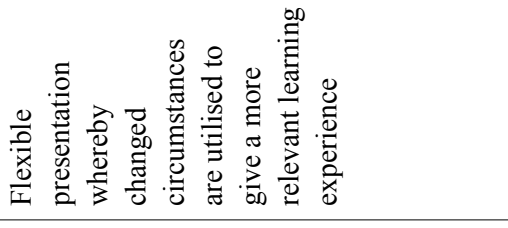 \\
\hline 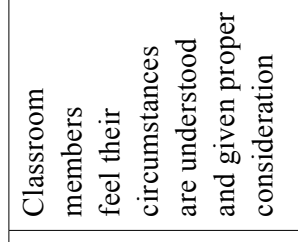 & & 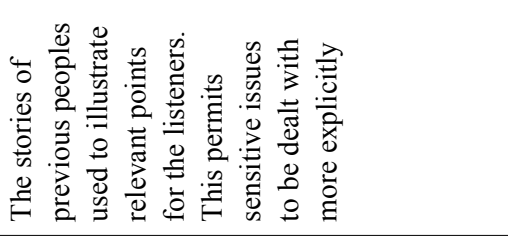 \\
\hline 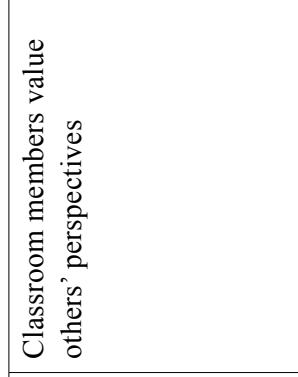 & & 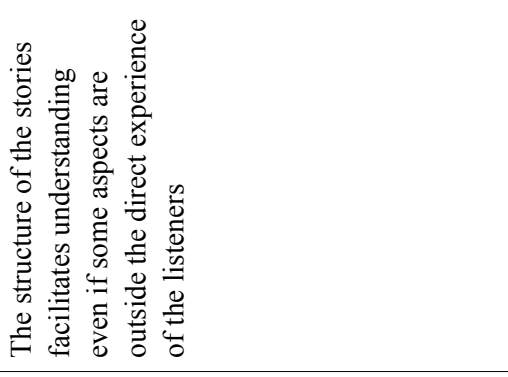 \\
\hline 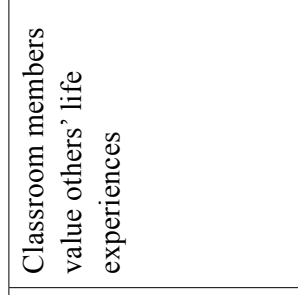 & & 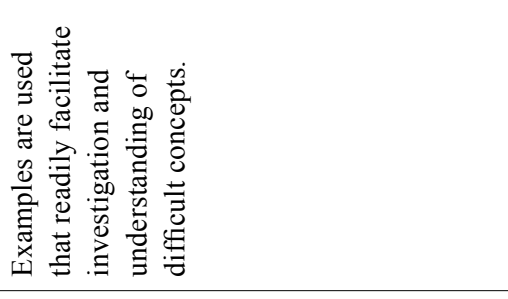 \\
\hline 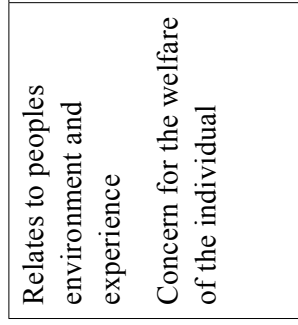 & 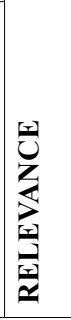 & 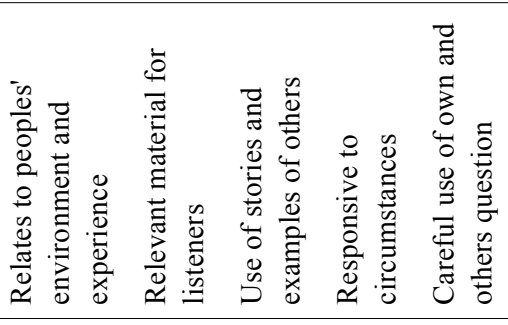 \\
\hline
\end{tabular}




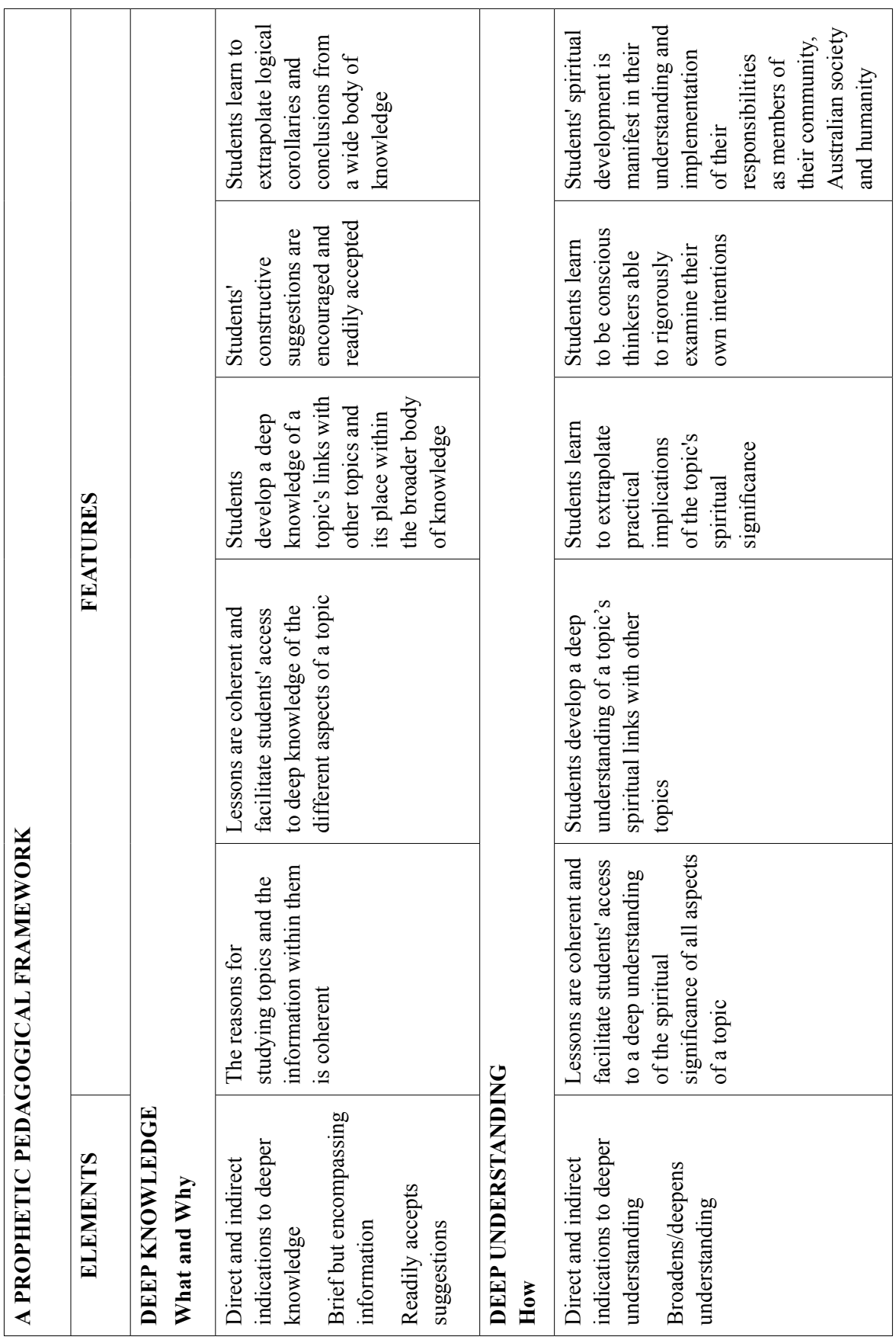




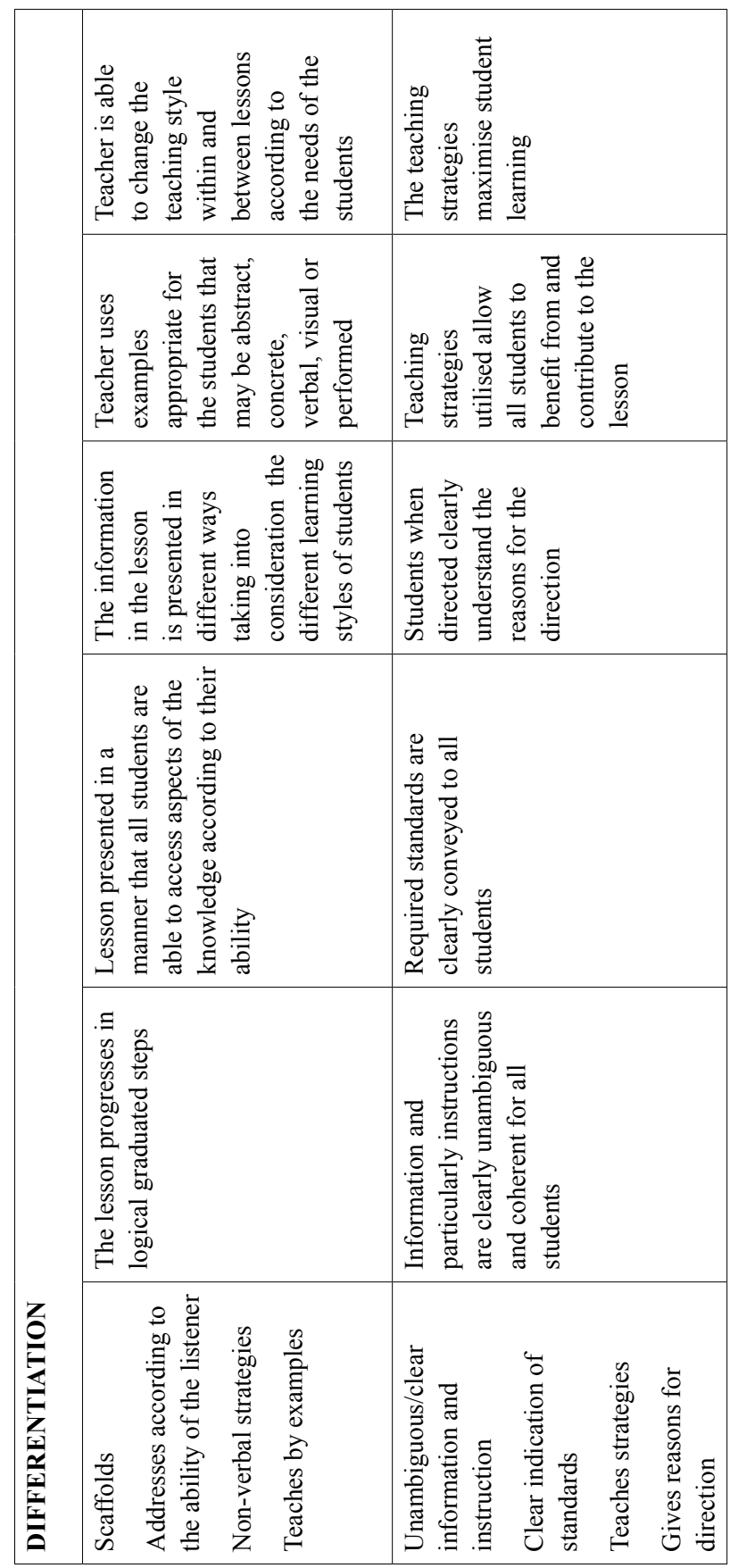




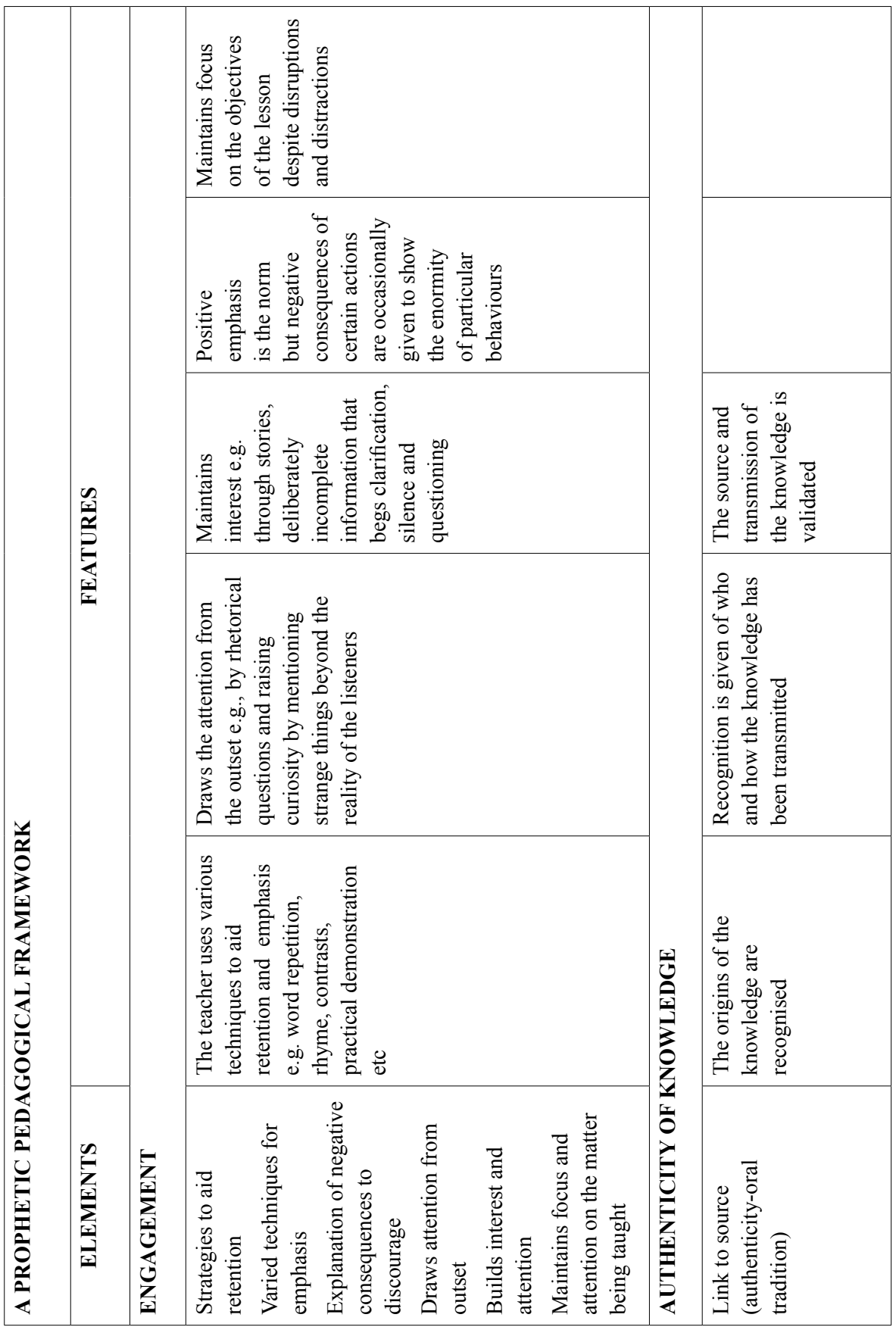




\begin{tabular}{|c|c|c|c|c|}
\hline \multicolumn{5}{|c|}{ 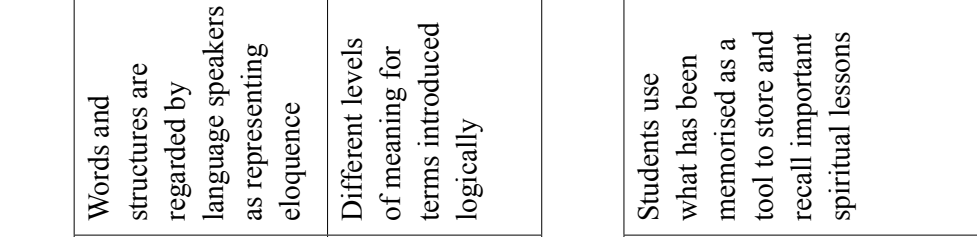 } \\
\hline & 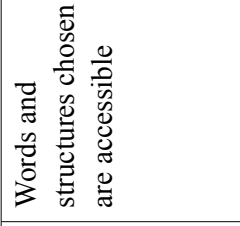 & 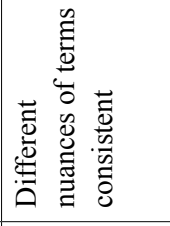 & & 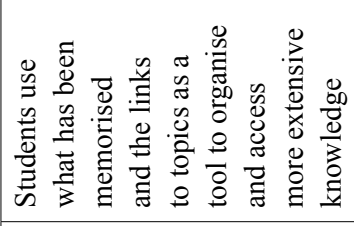 \\
\hline & 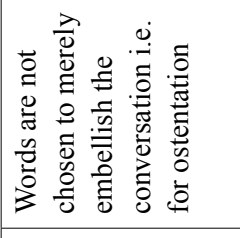 & 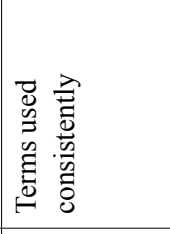 & & 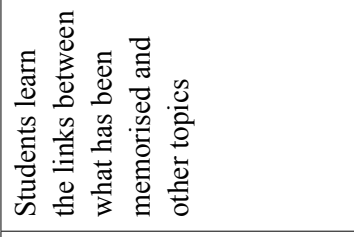 \\
\hline & 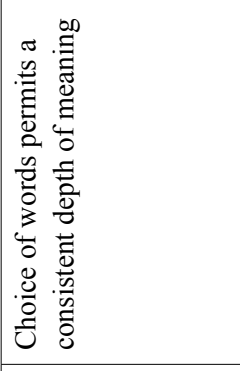 & 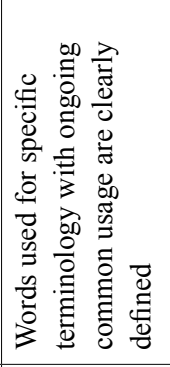 & & 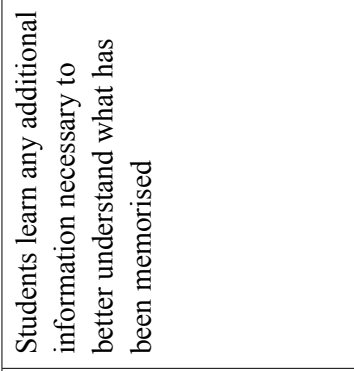 \\
\hline zo & 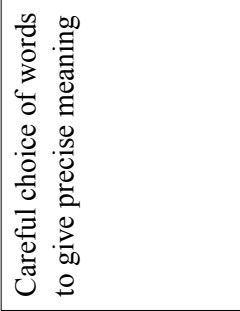 & 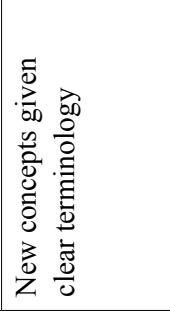 & 网 & 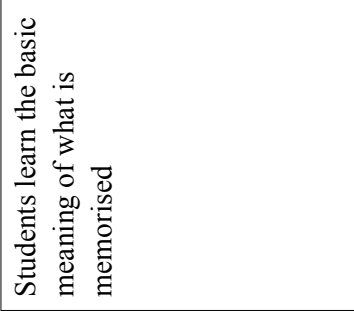 \\
\hline 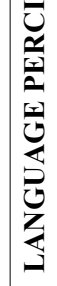 & 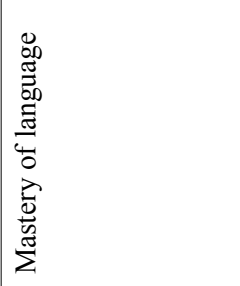 & 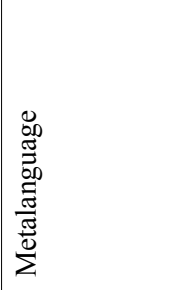 & 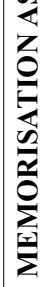 & \\
\hline
\end{tabular}


The features are the characteristics of the elements. Other Hadith to exemplify these characteristics have been taken from Sahih Muslim and other compilations of the hadith literature. A few examples of this are included at Table 3.

Table 3 Hadith that demonstrate features of an Element

\begin{tabular}{|c|c|c|}
\hline ELEMENT & FEATURE & EXAMPLES FROM HADITH \\
\hline & $\begin{array}{l}\text { Lesson presented in a } \\
\text { manner that all students are } \\
\text { able to access aspects of } \\
\text { the knowledge according to } \\
\text { their ability }\end{array}$ & $\begin{array}{l}\text { Imam Ahmad narrated from Abdullah } \\
\text { bin 'Amr bin Al-'Aas that he said; we } \\
\text { were with the Prophet of Allah (may } \\
\text { Allah grant him blessings and peace) } \\
\text { when a young man came and said; O } \\
\text { Messenger of Allah may I kiss (my } \\
\text { wife) when I'm fasting? He said; No. } \\
\text { An old man came and said; may I kiss } \\
\text { (my wife) when I'm fasting? He said; } \\
\text { Yes. We looked at each other so he } \\
\text { (may Allah grant him blessings and } \\
\text { peace) said; I know why you looked } \\
\text { at each other; the old man can control } \\
\text { himself. }\end{array}$ \\
\hline & $\begin{array}{l}\text { Teacher uses examples } \\
\text { appropriate for the students } \\
\text { that may be abstract, } \\
\text { concrete, verbal, visual or } \\
\text { performed. }\end{array}$ & $\begin{array}{l}\text { It is narrated from Abdullah bin } \\
\text { Masud that the Prophet (may Allah } \\
\text { grant him blessings and peace) drew a } \\
\text { rectangle with a line passing through } \\
\text { the rectangle lengthwise and smaller } \\
\text { lines from the side of the rectangle } \\
\text { perpendicular to the main line ... } \\
\text { Bukhari: The book of Riqaq; The } \\
\text { chapter of expectations }\end{array}$ \\
\hline
\end{tabular}


The work to formulate a Pedagogical Framework for Islamic schools from a synthesis of the proposed Prophetic Pedagogy and Productive Pedagogies is almost complete. Nevertheless it is clear from preliminary considerations that despite areas of difference there are sufficient similarities for the construction of a viable synthesis.

A very brief discussion follows to illustrate how a possible synthesis between some elements of the proposed Prophetic Pedagogy and dimensions of the Productive Pedagogies framework may be achieved. The Productive Pedagogies dimension that has been chosen for this illustration is Intellectual Quality. The elements of this dimension are Higher-order thinking, Deep knowledge, Deep understanding, Substantive conversation, Knowledge as problematic and Metalanguage. The definitions of these elements have been extracted from the Productive Pedagogies classroom reflection manual available from the Queensland Department of Education, Training and Employment website.

\section{i. Higher-order thinking:}

Higher order thinking involves students in the manipulation of information and ideas to synthesise, generalise, explain and hypothesise to arrive at a conclusion or interpretation. This element for those working in the Islamic sciences is just as if not more important than for those working in the material and social sciences. An Islamic scholar will constantly be required to synthesise complex material from a diverse number of fields before deciding an appropriate and authentic course of action in any given context. This is particularly so for scholars in the modern era and hence this element clearly has a place in a pedagogical framework for an Islamic school

However in addition memorisation was regarded in early Islamic education as an important tool in the facilitation of higher order thinking. It was not merely used for rote learning but intended as tool to aid later understanding of Islamic sciences and as means to synthesise, organise and access the vast amount of knowledge required by scholar to absorb before reaching decisions about essential matters in religious law (Hardaker and Sabki 2010 \& Boyle 2004). The inclusion of Memorisation as a key, within a concept of higher order thinking, in a pedagogical framework for Islamic schools would facilitate the redirection of memorisation that is currently undertaken from that of rote learning to its true place within an Islamic curriculum.

\section{ii. Deep knowledge}

Deep knowledge involves the establishment of relatively complex connections 
to the central concepts of a topic or discipline. On examination of the features outlined in this element of the Prophetic Pedagogical framework it is clear that there is a close fit between both frameworks. This element is essential for a student in an Islamic school so that they can not only connect across the common topics and disciplines of an Australian school education but between these topics and disciplines and their Islamic education.

\section{iii. Deep understanding}

A deep understanding is achieved when a student understands the complex relationships between the central concepts of a topic or discipline in a relatively systematic, integrated or holistic way. They can then produce new knowledge by discovering relationships, solving problems, constructing explanations and drawing conclusions. The emphasis of the esoteric rather than the exoteric in the proposed Prophetic pedagogy element Deep understanding is not at odds with Productive pedagogies but rather adds a deeper dimension for Muslim students. This emphasis lies at the core of an Islamic understanding not only of the holistic nature of Islamic knowledge but of all knowledge and the importance, interconnectedness and integrated nature of all thought and action.

\section{iv. Substantive conversation}

Through substantive conversation between teacher and students the understanding of subject matter is created or negotiated. This should include discussion about language, grammar, technical vocabulary and text structures and how these impact on, and are impacted by, different discourses and ideologies. The proposed Prophetic Pedagogy element Language Precision encompasses the mastery of language. It lies at the core of the Productive Pedagogies element. Substantive conversation as it develops through substantive, logical and precise conversation, analysis and synthesis of the ideas, reasoning and conclusions of bodies of knowledge. As such Language Precision may be regarded as an important area within the Substantive conversation element of Productive Pedagogies,

\section{v. Knowledge as problematic}

The Productive Pedagogies element Knowledge as problematic involves the critical examination of texts, ideas and knowledge and although not explicitly part of the proposed Prophetic pedagogy should be included in a synthesis. It is essential for students who are a minority in a society of many cultures. It assists them to better understand the subtleties of the influences to which they and others are exposed. Students in an Islamic school need to gain an 
understanding of how knowledge is constructed, how conflicting forms of knowledge are presented and how this impacts on the individual and society in general.

\section{vi. Metalanguage}

Metalanguage instruction incorporates frequent discussion about talk and writing, about how written and spoken texts work, about specific technical vocabulary and words, text structures and specific discourses. In the time of the Prophet people were highly orally literate and understood the nuances of language. It was important that the Prophet carefully explained the differences in terminology and understanding that Islam brought to the use of language. How more important for the teacher in an Islamic school to give great importance to metalanguage in a time when influence and manipulation through oral, written and visual genres has gained prominence as a tool for the spread of diverse ideologies and perspectives from around the world.

\section{Conclusion}

The elements and features identified above of the Prophet's pedagogy are not necessarily exhaustive. They are not exactly the same as those identified in the QSRLS however they have significant areas of overlap. The recognition of this overlap should give teachers in Islamic schools the basis upon which to evaluate and use where applicable the various pedagogical frameworks that are based upon current research. Although the finalisation of the construction of a Pedagogical Framework for Islamic schools is currently underway the achievement of such a framework is in reality only a first step and is not intended as a panacea or a model to be mechanically learnt and implemented. It is rather a tool, that gives all educators in an Islamic school both of "religious and secular" subjects a common metalanguage and framework for discussion of quality teaching based on Prophetic tradition and contemporary Australian educational thought. It is therefore recommended that:

- Each Islamic school undertake a review of current pedagogical practices across all curriculum areas.

- Conversations about pedagogy are initiated in Islamic schools across all curriculum areas both "religious and secular".

- A consistent pedagogy is developed across all curriculum areas of the Islamic school.

- Training and Development funding be used to assist teachers in the development of their pedagogical practices. 
- Untrained practitioners in Islamic schools, particularly those in the area of the Islamic Sciences, are funded to under go teacher training.

\section{Notes}

* Muhammad Abdullah is a PhD candidate at the National Centre of Excellence for Islamic Studies, Griffith University, Brisbane, Australia.

** Mohammad Abdalla is an Associate Professor in Islamic Studies, and Founding Director of the National Centre of Excellence for Islamic Studies (GU Node), Brisbane, Australia.

*** Robyn Jorgensen is Professor of Education, University of Canberra, Australia.

\section{Acknowledgement}

We would like to thank Sheikh Abdul Moez Nafti, the former President of The Australian National Imams Council and Director of Daar Aishah for examining some of the ahadith discussed in this document.

\section{Bibliography}

Ali, S. B. (2003) Scholars of Hadith. Skokie: IQRA' International Educational Foundation.

Al-Attas S. M. (1976) Islam and Secularism. Kuala Lumpur: Muslim Youth Movement of Malaysia (ABIM).

Al-Attas, S. M. (1980) The Concept of Education in Islam. Kuala Lumpur: Muslim Youth Movement of Malaysia (ABIM).

Alwan, A. N. (2005) Tarbiyatul Aulaad fil Islam. Cairo: Dar Al-Salaam.

An-Nawawi, Imam (2003) Riyadhus Salihiin. Cairo: Daarul hadith.

Barazangi, N. H. (1998) The Equilibrium of Islamic Education: Has Muslim Women's Education Preserved the Religion? Religion and Education, 25(1 \& 2) 5-19.

Boyle, H. N. (2004) Qur'anic Schools: Agents of Preservation and Change. New York: Routledge Farmer.

Buckingham, J. The Rise of Religious Schools in Australia, Centre for Independent Studies (Australia). Policy Monograph 111, 16 September 2010.

Cleland, B. (2001) A History of Islam in Australia retrieved on 27 $7^{\text {th }}$ April 2009 from http://www.islam.iinet.net.au/channel/islam_australia.html.

Clyne Donohoue I. (2000) The Struggle of Muslims to educate their children in Australia. PhD Theses University of Melbourne Retrieved May 182009 from University of Melbourne Library. 
Driessen, G. W., \& Bezemer, J. J. (1999) Background and Achievement Levels of Islamic Schools in the Netherlands: are the reservations justified? Race Ethnicity and Education, 2(2) 235 - 256.

Driessen, G. \& Merry, M. S. (2006) Islamic Schools in the Netherlands: Expansion or Marginalization. Interchange, 37(3) 201-223.

Du Pasquier, R. (2002) Unveiling Islam. Translation by T. J. Winter, Cambridge: The Islamic Texts Society.

Education Queensland (2001) Productive Pedagogies. Retrieved September, 23, 2009 from http://education.qld.gov.au/curriculum/learning/teaching/technology/ pedagogy/ index.html.

Glaser, B. G. (1978) Theoretical Sensitivity: Advances in the methodology of Grounded Theory. Mill Valley, Sociology Press.

Halstead, Mark J. (2004). An Islamic concept of Education. Comparative Education, 2(4), 5-17.

Hayes, D., Mills, M., Christie, P., \& Lingard, B. (2006). Teachers and Schooling Making a Difference, Crows Nest: Allen and Unwin.

Hodge D. R. \& Nadir A. (2008) Moving toward Culturally Competent Practice with Muslims: Modifying Cognitive Therapy with Islamic Tenants. Social Work 53 (1)

Holloway, I. (2008) A-Z of Qualitative Research in Healthcare $2^{\text {nd }}$ Edition. Chichester: Blackwell Publishing.

Ihram, S (2007) Islamic schools neglecting critical role,. Islamic Education Consultancy Retrieved on September, 24, 2009 from www.islamiceducation.com.au.

Kamali, M. H.(2005) A textbook of Hadith Studies. Markfield: The Islamic Foundation.

Marley, D., (2008) Muslim schools prove stars of the higher-performing faith family, News Article Published in The TES on 19 December, 2008.

Meer, N. (2007) Muslim Schools in Britain: Challenging mobilisations or logical developments? Asia Pacific Journal of Education 27(1) 55-71.

Memon, N. Ahmed Q. (2006) The pedagogical Divide: Toward an Islamic Pedagogy. Paper presented at ISNA Education Forum 2006 Rosemont Illinois Retrieved May, 2, 2009 from http://www.isna.net/programs/pages/previous-education-forum-papers. aspx.

Memon, N. (2007) The Prophetic Standard, Paper presented at ISNA Education Forum 2007 Rosemont Illinois Retrieved May, 2, 2009 from http://www.isna.net/ programs/pages/previous-education-forum-papers.aspx.

Merry, M. S. (2005) Advocacy and Involvement: The Role of Parents in Western Islamic Schools, Religious Education, 100(4), 374-385.

Merry, M. S. \& Driessen, G. (2005) Islamic schools in three countries: policy and procedure. Comparative Education 41(4), 411-432. 
Mills, M., Goos, M., Keddie, A., Honan, E., Pendergast, D., Gilbert, R., Nichols, K., Renshaw, P., \& Wright, T. (2009) Productive Pedagogies: A Redefined Methodology for Analysing Quality Teacher Practice, The Australian Educational Researcher, Vol. 36(3), pp. 67-87.

Moes, M (2006) Islamic Schools as Change Agents. Paper presented at ISNA Education Forum 2006 Rosemont Illinois. Retrieved May, 2, 2009 from http://www. isna.net/programs/pages/previous-education-forum-papers.aspx

Murad, A (2001) The Essence of Islamic Education. Recorded audio lecture. Ihya Productions.

Murad, Abdul Hakim (aka Timothy Winter) (1997). British and Muslim? Retrieved May 25, 2008, from http://www.masud.co.uk/ISLAM/ahm/british.htm.

Raihani \& Gurr, D. (2010), "Parental Involvement in an Islamic School in Australia: An Exploratory Study", Leading and Managing Journal, Vol. 16, No.2, pp. 62-76.

Sanjakdar F. (2001) Educating Muslim Children: A Study of the Hidden and Core Curriculum of an Islamic school University of Melbourne Retrieved April, 27, 2009 from https://www.aare.edu.au/01 pap/san01187.htm

Sanjakdar F. (2005) Teachers' struggle for an Islamically appropriate sexual health education curriculum at their school University of Melbourne. Retrieved April, 27, 2009 from https://www.aare.edu.au/05pap/san05732.htm

Shadid, W. A. R., Van Koningsveld, P. Sj (1992). Islamic Primary Schools In W. A. R. Shadid, \& P. Sj.Van Koningsveld, (Eds.) Islam in Dutch Society: Current Developments and Future Prospects (pp107-123) Kampen: Kok Pharos Publishing House.

Shamma, F. (1999) The Curriculum Challenge for Islamic Schools in America. In Amber Haque (Ed.) Muslims and Islamization in North America: Problems and Prospects (pp. 273-295). Beltsville, MD: Amana Publications.

Tauhidi D. (2001) Tarbiyah Project in Depth. Retrieved June, 17, 2009 from www.4islamicschools.org/tarbiyah.htm.

Urquhart, C. (2001) An encounter with grounded theory: Tackling the practical and philosophical issues In E. Trauth (ed.), Qualitative Research in Information Systems: Ideas and Trends (pp.104-140). London: Idea Group Publishing.

Walford, G. (2002). Classification and Framing of the Curriculum in Evangelical Christian and Muslim Schools in England and The Netherlands. Educational Studies 28(4), 403-419

Watson K. \& Chen X. (2008). Preserving cultural heritage: An Australian Islamic perspective. Pacific Asian Education, 20 (1) 33-46

Wise A. \& Ali J. (2008) Muslim Australians and Local Government. Final Research Report for the Centre for Research and Social Inclusion 22April 2008, Retrieved June, 17, 2009 from http:/www.immi.gov.au/media/publications/multicultural/grassroots/ 